Данник Катерина Олександрівна

ORCID ID 0000-0002-5257-8862

аспірант,

Київський національний університет

культури і мистецитв

Київ, Украӥна

katlina17@gmail.com

\title{
КУЛЬТУРНА ДІЯЛЬНІСТЬ ВІРМЕНСЬКОЇ ДІАСПОРИ В СУЧАСНІЙ УКРАЇНІ
}

Мета роботи. Метою дослідження $\epsilon$ аналіз культурнодозвіллєвих заходів, що організовуються вірменськими громадами в сучасному українському соціокультурному просторі. Методологія дослідження полягає у застосуванні аналізу теоретичної бази з тематики вірменських громад для виявлення закономірної специфіки, згідно з якою відбуваються культурні процеси в межах вірменської діаспори нашої країни. Для збору первинної інформації використано методи інтерв'ювання та опитування діячів вірменської культури, а також спостереження та аналіз заходів і проектів, що проводяться вірменськими товариствами. На прикладі декількох проектів виявлено, що всеукраїнська кооперація призводить до масштабних та значимих заходів. Наукова новизна. Вперше на основі матеріалів національних громад проаналізовано культурно-дозвіллєву 
діяльність вірменських товариств. За допомогою польових досліджень проведено класифікацію культурних заходів вірменської діаспори та охарактеризовано їхні особливості. Висновки. Встановлено, що вірменська діаспора України має розгалужену та збалансовану систему національних товариств, які активно впроваджують численні заходи та проекти 3 метою популяризації культури та збереження своєї самобутності; охарактеризовано взаємозв'язок світського і церковного життя вірмен; здійснено класифікацію заходів вірменської культури; проведено порівняльну характеристику локальних та всеукраїнських проектів. 3'ясовано вплив вірменських проектів на загальноукраїнську громадськість. Закладено базу до проведення дослідження вірменської діяльності в напрямку науковопросвітницької та пам'яткоохороноої діяльності.

Ключові слова: вірмени, культурно-дозвіллєва діяльність, громада, виставка, фестиваль, свято, концерт.

Данник Екатерина Александровна, аспирант, Киевский национальньй университет культуры и искусств. Киев, Украина

Культурная деятельность армянской диаспоры в современной Украине

Цель работы. Целью исследования является анализ культурно-досуговых мероприятий, организуемых армянскими общинами в современном украинском социокультурном пространстве. Методология исследования заключается в применении анализа теоретической базы по тематике армянских 
общин для выявления закономерной специфики, согласно которой происходят культурные процессы в пределах армянской диаспоры нашей страны. Для сбора первичной информации использованы методы интервьюирования и опросов деятелей армянской культуры, а также наблюдение и анализ мероприятий и проектов, проводимых армянскими обществами. На примере нескольких проектов обнаружено, что всеукраинская кооперация приводит к масштабным и значимым мероприятиям. Научная новизна. Впервые на основе материалов национальных общин проанализирована культурно-досуговая деятельность армянских обществ. С помощью полевых исследований проведена классификация культурных мероприятий армянской диаспоры и охарактеризованы их особенности. Выводы. Установлено, что армянская диаспора Украины имеет разветвленную и сбалансированную систему национальных обществ, которые активно внедряют многочисленные мероприятия и проекты с целью популяризации культуры и сохранения своей самобытности; охарактеризованы взаимосвязь светской и церковной жизни армян; осуществлена классификация мероприятий армянской культуры; проведена сравнительная характеристика локальных и всеукраинских проектов. Выяснено влияние армянских проектов на всеукраинскую общественность. Заложена база к проведению исследования армянской деятельности в направлении научнопросветительской и деятельности по орхане памятников.

Ключевые слова: армяне, культурно-досуговая деятельность, общество, выставка, фестиваль, праздник, концерт. 
Dannyk Kateryna, postgraduate, Kyiv National University of Culture and Arts, Kyiv, Ukraine

\section{Cultural activity of the Armenian diaspora in modern Ukraine}

The purpose of the article is to analyze cultural and leisure events organized by Armenian communities in the modern Ukrainian sociocultural space. The research methodology consisted in the analysis of the theoretical basis on the topics of Armenian communities in order to identify the logical specificity which determined the cultural processes within the Armenian diaspora of our country. To obtain raw data, methods of interviewing and polling activists of Armenian culture, as well as observing and analyzing events and projects conducted by Armenian societies, were used. Through the example of several projects, it was revealed that all-Ukrainian cooperation led to large-scale and significant events. The scientific novelty of the work. For the first time, based on the materials of national communities, the cultural and leisure activity of Armenian societies was analyzed. With the help of field study, cultural events of the Armenian diaspora were classified and their features were characterized. Conclusions. It was established that the Armenian diaspora of Ukraine has an extensive and balanced system of national societies that actively implement numerous events and projects aimed at popularizing the culture and preserving their identity; the interrelationship between secular and church life of Armenians was characterized; the classification of events of Armenian culture was carried out; a comparative description of local and all-Ukrainian projects was given. The influence of Armenian projects on the national 
Ukrainian society was revealed. The basis for conducting research into Armenian activity in the direction of scientific-educational activity and protection of cultural heritage was laid.

Key words: Armenians, cultural and leisure activity, community, exhibition, festival, holiday, concert.

Вступ. Після проголошення незалежності України в 1991 р. спостерігається пожвавлення діяльності національних товариств завдяки лояльному законодавству, яке надає підстави вільно розвивати національну культуру та реєструвати громадські об’єднання. Україна, як сучасна демократична країна, зацікавлена в тому, щоб іiі громадяни мали цікаве, пізнавальне та розважальне дозвілля, що впливає на суспільний інтелектуальний рівень культурного життя нації. Особливістю діяльності вірменських громад України є те, що вони спрямовують свою активність на культурно-просвітницькі проекти та збереження вірменських матеріальних і нематеріальних пам'яток. Таким чином, культурні заходи вірменських громад виступають важливим компонентом соціокультурного життя України, а їх дослідження сьогодні $€$ досить актуальним.

Мета роботи - охарактеризувати найважливіші та наймасштабніші культурні заходи вірменських громад та проаналізувати їх як важливе соціокультурне явище в українському культурному просторі.

Аналіз останніх досліджень та публікацій. Базове теоретичне пояснення особливостей вірменської діаспори 
здійснено спеціалістом з теорії діаспор В. Дятловим та теоретиком вірменської діаспори Е. Мелконяном [10]. Дослідження правових аспектів організації діяльності вірменських громад належить соціологу Н. Бережній [1]. Специфічні особливості вірменської діаспори України описані дослідницею вірменської церкви та культури І. Гаюк [7]. Враховуючи обрану тематику, яка висвітлює сучасний етап культурного життя України, актуальним джерелом $є$ офіційні сайти вірменських громад $[2 ; 3 ; 4 ; 5 ; 9 ; 16]$, де періодично висвітлюються найважливіші події, пов’язані з діаспорою в Україні та світі. Отже, наявні публікації представлені переважно публіцистикою 3 місцевих 3MI, яким бракує не лише наукового осмислення і аналізу, а й класифікації. Крім того, інформація про культурну діяльність вірменських громад в незалежній України досі не була зведена в єдиній роботі, що дала б комплексне уявлення про місце вірмен в сучасній українській культурі. Виходячи із вищенаведеного, формулюємо проблему, що полягає у потребі наукового осмислення вірменської культурної діяльності в сучасному українському просторі.

Виклад основного матеріалу. Згідно 3 Всеукраїнським переписом населення, який було здійснено в 2001 р., в Україні проживає 99,9 тис. вірмен, що в 1.8 разів більше в порівнянні 3 1989 р. [14]. Однак, як влучно зазначає дослідниця вірменських товариств Н. Бережна за неофіційними, але звіреними даними за 2012 р. в Україні приживало понад 400 тис. вірмен [1, с. 112]. Згідно з 11 статтею Першого розділу Конституції України, держава сприяє консолідації та розвиткові української нації, етнічної, 
культурної, мовної та релігійної самобутності всіх корінних народів і національних меншин $[11$, с. 5]. Однак, враховуючи законодавчоправову систему України, варто проаналізувати, як на практиці реалізовуються ці положення.

Питання ролі національних меншин у культурному просторі України є важливим в контексті дослідження вірменських громад та виявлення перспектив їх життєдіяльності. Варто зазначити, що кожна національна громада має на меті певні цілі, виконання яких $є$ для неї пріоритетним напрямком, і в які вона вкладає свої ресурси. Саме тому, в багатонаціональному українському суспільному русі важливими $є$ дані щодо основних напрямків і завдань діяльності тієї чи іншої національної меншини та їі організацій. В. Дятлов, спеціаліст з теорії діаспор слушно зазначає, що сукупність людей певного етносу, які проживають поза межами своєї рідної країни, це не діаспора, а лише необхідна передумова іiі існування. Вчений розуміє діаспору як особливий тип людських взаємин, специфічну систему формальних і неформальних зв'язків, життєвих стратегій і практик людей $[10$, с. 25]. Інакше кажучи, наявність певної кількості вірмен за межами Вірменії- це лише формально $\epsilon$ діаспора. Тобто, справжньою діаспорою $є$ сформована у національну громаду спільнота людей, яка прагне зберігати свою культурну самобутність та, водночас, інтегруватись в українське демократичне суспільство. Із проголошенням незалежності України спостерігається активізація вірменських громад, що пов'язано 3 лояльним законодавством. Зокрема, згортання атеїстичної пропаганди в межах радянської ідеології дало змогу вірменським 
громадам зводити храми і проводити церковні служби рідною мовою. Згідно з твердженням Е. Мелконяна, дослідника-теоретика вірменських громад, для функціонування діаспори, як певної етнокультурної цілісності, особливу роль відіграють пандіаспоральні організації, головною 3 яких вчений називає Вірменську Апостольську церкву [10, с. 132]. Вірменська церква є не лише носієм духовності усіх вірмен світу, а й потужним, об’єднуючим та координуючим механізмом, що виступає значною підтримкою в функціонуванні вірменських громад.

Єдність вірменських громад України існувала ще 3 середньовічного періоду. На думку I. Гаюк, дослідниці вірменського культурного осередку на українських теренах, специфікою вірменських колоній різних регіонів було те, що вони завжди підтримували між собою досить тісні зв'язки, не зважаючи на політичну ситуацію, що їх оточувала [7, с. 156].

Рівень культурного розвитку людини може визначатись багатьма чинниками, зокрема iï мовленням, поведінкою та дозвіллям. У цьому контексті види дозвіллєвої діяльності національних громад здійснюють вплив на культурний сектор України та формують автентичний і оригінальний продукт. Під таким продуктом розуміємо поняття «культурно-дозвіллєвий захід вірменської громади», що є принципово оригінальним і має свої особливості. Для конкретнішого уявлення сутності цього поняття та розуміння його як соціокультурного феномену в сучасному українському просторі пропонуємо його класифікацію. 
Так, культурні заходи вірменської громади України за напрямками поділяються на: дні культури; кіно-, літературно-, музичні вечори; виставки; конкурси; фестивалі; концерти; національні та церковні свята; дні геноциду.

За формою участі ці заходи поділяються: ініційовані власне вірменською громадою, та ті, в яких громада або іiі представники беруть участь. Виявимо особливості кожного заходу за допомогою аналізу його сутності та конкретних прикладів.

Найбільш розповсюдженим заходом, який нерідко проводиться багатьма національними меншинами є день культури. Метою такого свята $є$ ознайомлення жителів певного осередку 3 національними меншинами, що проживають в цьому населеному пункті. У періодиці знаходимо численні повідомлення про дні культури в Кам’янці-Подільському, Чернівцях, Одесі, Києві та інших містах, де активно функціонують національні вірменські товариства. Одним із перших та знакових заходів такого виду, був організований в липні 2005 р. «Вірменський дворик» в Кам'янціПодільському, на Ратушній площі. 3 нагоди дійства було встановлено будиночок, який прикрашали старовинні меблі, кухонне начиння і традиційні вірменські дерев'яні вироби 3 різьбою та картини, а гостей пригощали традиційними стравами. 3 Києва було привезено пересувну виставку сучасних українських митців вірменського походження. Серед експонатів- чеканка С. Тиграняна, вишивка Ф. Оганесян, гобелени А. Хачатрян та колажі Н. Чиркінян, виконані зі шкіри, намиста, бісеру, стрічок і ниток [8]. Нерідко, вірменська культура буває репрезентована в 
рамках фестивалю «Острів семи скарбів», що проходить у другій декаді травня, коли національні меншини Кам'янця представляють різноманітні елементи своєї культури. У Києві вже втретє в 2017 р. пройшов фестиваль «Культури народів Подолу», за підтримки Спілки вірмен України, де вірмени також приймають участь, представляючи свою культуру за допомогою народних страв, виставки дитячих малюнків тощо [19]. Ще однією вагомою подією $\epsilon$ щорічний фестиваль Outlook world culture [18], який пройшов вже вчетверте 7 жовтня 2017 р. у приміщенні КМДА. Активну участь у цьому заході прийняла Спілка вірмен України Миколаївської області та вірменський жіночий комітет. Представники громад проводили майстер-класи 3 вірменської писемності, вокалісти групи «Бельканто» заспівали пісню «Айястан» (3 вірм. Батьківщина), було представлено вірменський тараз (національне вбрання).

Наведені заходи сфорормували такі висновки: дні національних культур - невід'ємна і важлива частина соціокультурного простору поліетнічної держави. Участь національних громад у таких заходах сприяє загальному розвиткові громадян і виховує в них повагу і шану до меншин, що проживають в Україні. Також дні культури нерідко організовуються самою вірменською громадою на теренах певного закладу: загальноосвітньої чи недільної школи, бібліотеки тощо. Наприклад, у 2015 р. Чернігівська вірменська громада влаштувала презентацію вірменської культури за підтримки і в приміщенні обласної універсальної наукової бібліотеки ім. Короленка [6]. 
У рамках днів Вірменії в Україні особливо активно проходили різноманітні заходи в 2011 р., під час офіційного візиту президента Республіки Вірменії С. Саркісяна. 3 цієї нагоди було влаштовано низку літературних, художніх та інших культурних заходів: 30 червня - 5 липня відбувались покази фільмів В. Чалдраняна «Ретроспектива Вірменського кіно» (Національний будинок кіно); 02-13 липня - виставка робіт В. Суренянца з колекції Національної галереї Вірменії (Національний музей літератури України); 2 липня - творча зустріч 3 письменниками Вірменії та України (Національна спілка письменників України); 2 липня фотовиставка «Вірменський слід в Україні» (Національна опера України, 4 липня- Одеський національний академічний театр опери та балету); 2 липня - гала-концерт майстрів мистецтв Вірменії (Національна опера України, 4 липня - Одеський національний академічний театр опери та балету) [9].

Наступний вид заходів пов'язаний 3 кіномистецтвом. Як відомо, Україну і Вірменію пов'язує багато подій, дотичних до кіно. Зокрема, варто згадати вражаючий успіх кінокартини про життя і побут гуцулів - «Тіні забутих предків» за мотивами твору М. Коцюбинського, яку зняв вірменський режисер С. Параджанов. Значна кількість кінозаходів, присвячених пам'яті С. Параджанова, ініційована вірменським товариством культурних зв'язків «АОКСУкраїна». Наприклад, у 2009 р. в Українському фонді культури відбувся творчій вечір С. Параджанова, присвячений 45-літтю виходу фільму «Тіні забутих предків» [4]. У межах цього проекту проведена не лише зустріч представників української інтелігенції 
(дружина режисера - С. Щербатюк, режисер Р. Балаян, співачка Т. Аветісян, художник Б. Сгіазарян, музиканти А. Костандян та А. Берберян), а й задіяна цікава концертна та художня програма. Через два роки відбувся дещо подібний захід, вже в столичному музеї Ш. Алейхема, який мав назву «In Memoriam. Сергей Параджанов». До кіно-заходів відносимо засідання кіно-клубу, що проходять в рамках проекту Parajanov-ART. Розпочинаючи 3 2004 p. і до сьогодні, було проведено більше ніж 100 засідань, присвячених творчості кіномитця, у 67 містах та містечках по всій Україні. Важливою складовою кіно-вечорів є культурологічний аналіз творчості режисера, який проводить О. Оганесян, засновуючись на особистому досвіді спілкування 3 С. Параджановим та його дружиною. Найчастіше коментуються уривки з таких фільмів як: «Тіні забутих предків», «Колір граната», «Легенда про Сурамську фортецю», «Андрієш», «Перший парубок», «Українська рапсодія», «Квітка на камені» тощо.

Виставки найчастіше презентують вірменський вплив в українській культурі шляхом показу арт, фото-робіт. Вірменські громади організовують виставки дитячих робіт для заохочення молоді до творчості та пізнання давньої історії свого народу. Перша виставка дитячої творчості відбулась у 2000 р. в Трапезній Львівського Домініканського собору, за сприянням вірменської громади та єпархії Вірменської Апостольської церкви України. Тоді було закладено традицію проведення багатонаціонального фестивалю з творчою та концертною програмою. 
Окрім виставок дитячої творчості, вірменськими громадами організовуються художні виставки робіт як вірмен з України, так і майстрів 3 Вірменії. Для прикладу наведемо виставку майстра декоративно-прикладного мистецтва i петриківського розпису М. Саркісян, що відбулась 3 лютого та 26 червня 2017 р. в Будинку вчителя в Українському фонді культури. Відомо, що на останньому заході було представлено більше ніж 60 картин, над якими мисткиня працює з 2009 р. [5]. Інший варіант організації художніх виставок репрезентує проект, реалізований в київському Шоколадному будиночку 8-17 вересня 2017 р. Захід підтримала й прийняла в ньому участь місцева вірменська громада та церква, а також молоді музиканти. Поряд із проведенням виставок сучасного мистецтва, вірмени прагнуть зберегти своє класичне мистецтво. Так, 22 листопада 2017 р. у бібліотеці ім. Вернадського пройшла вже третя виставка репродукцій вірменських ікон (дві попередні виставки мали місце в київському Будинку архітектора та в Житомирі).

Підтримку дитячої творчості продовжує товариство АОКСУкраїна, шляхом оголошення всеукраїнських конкурсів через Міністерство освіти і науки України, Міністерство культури (Департамент у справах національностей i релігій), соціальні мережі. Згідно 3 підсумковим альманахом, який був виданий в 2016 р., за 10 років у межах проекту, що має назву «Моя Батьківщина - очима дітей етносів України» було проведено: Шість всеукраїнських історико-літературних конкурсів: («Про історію і культуру Вірменії та вірмен, які проживають в Україні» (2006- 
2007 рр.), «Моя батьківщина - очима дітей етносів України» (20082009 рр.), «Лицарі українського романтичного світосприйняття. М. Коцюбинський, С. Параджанов» (2009-2010 рр.), «Моя Батьківщина. 1000-річчя заснування Софії Київської присвячується» (2011-2012рр.), «Моя Батьківщина. 1025-річчя хрещення Київської Русі присвячується» (2012-2013 рр.), «Лицарі романтичного світосприйняття. М. Коцюбинський, С. Параджанов» (2014-2015 рр.); Всеукраїнський художньо-просвітницький конкурс: «Моя Батьківщина. Пам’яті Михайла Бароянца»; Чотири Всеукраїнських конкурс-фестивалі авторської патріотичної пісні: «Моя Батьківщина. Пам’яті Олександра Авагяна» (2013-2016 рр.); одинадцять підсумкових науково-практичних конференцій (20092016 pp.) [13, c. 2].

Проведені заходи були спрямовані на заохочення i нагородження дитячої творчості. Після закінчення кожного 3 конкурсів, кращі роботи виставляють на виставках багатьох міст України. Усі проекти товариства АОКС, реалізуються на волонтерській основі, а тому локації, де проводяться виставки, засідання кіно-клубу, конференції та інші заходи, є, найчастіше, музеями та будинками народної творчості, які згодились на неприбуткову справу задля розвитку української культури. Зокрема, такими закладами є: Трапезна Софії Київської, Меджибізька фортеця, музей книги Києво-Печерської лаври, музей Ш. Алейхема, Т. Шевченка, I. Франка, Хмельницька обласна філармонія, Космацький та Лубенський будинки творчості та ін. 
До категорії літературних вечорів відносяться не лише заходи, де проходить декламація вірменської та української поезії, а й презентації книжок, виданих за сприяння вірменських громад. Так, 18 квітня 2017 р., у столичному Домі актора відбувся літературний вечір «Псалом Вірменії» 3 презентацією трьох книг: Н. Нікітенко «Від Царгорода до Києва» (6-е видання), Б. Чичибабін «У серці моєму болить Вірменія», Л. Вишеславський «Вірменська балада» [15]. Протягом свята, національного колориту додали вірменські пасхальні піснеспіви від Київського хору вірменської апостольської церкви. Прикметно, що значна кількість різножанрових заходів часто супроводжується музичними номерами, чому сприяють окремі представники творчої вірменської інтелігенції та українська єпархія вірменської апостольської церкви. Вищенаведені факти ще раз підтверджують тезу Е. Мелконяна про важливу роль церкви в будь-якій сфері діяльності вірменських громад [10, с. 132], зокрема, й в культурній.

Визначною подією в контексті літературних заходів також стала презентація віршів видатного українського письменника та дисидента, В. Стуса вірменською та українською мовами. Значна заслуга в цьому вірменина, Р. Маркосяна, який відбував покарання разом із Стусом в Мордовських таборах, і завдяки йому вдалось зберегти 58 віршів поета і видати збірку «О Боже, тиші дай» (вірменською мовою) [17]. Серед почесних гостей презентації були такі: перший посол України у Вірменії - О. Божко, директор музею Т. Шевченка - Д. Стус, заслужений артист України, кінорежисер Р. Балаян та інші. Літературні читання доповнив майстер дудуку, 
учень славетного джаз-мена А. Алексаньяна, А. Костандян пронизливими і глибокими вірменськими мелодіями.

Музичні вечори часто супроводжуються пам'ятними заходами на честь видатних вірменських музикантів. Зокрема, щорічно відзначається день народження українського спелеолога, археолога та музиканта О. Авагяна, який в 60-х pp. XX ст. заснував гурт «Березень» (прикметно, що у радянський період юнаки наважились співати українських пісень та, нерідко, присвячувати їх українському побутові та християнським звичаям). Тому на святах, присвячених О. Авагяну, часто лунають пісні та вірші його авторства у виконанні друзів та знайомих, серед яких представники київської інтелігенції: В. Вітер, В. Криштофович, П. Маркман та ін. 12 и 13 листопада 2014 р., 3 нагоди 70-річчя 3 дня народження Авагяна відбулась зустріч в столичному Домі архітектора [3]. Музичні номери пролунали від представників молодого покоління (М. Куртікян, В. Королюк), які вже не були знайомі з Авагяном, однак досі надихаються його творчістю. Завдяки громадській ініціативі об’єднання вірменських жінок та сприянню «Центру вірменської культури Наірі», проводяться літературно-музичні вечори. Один із таких заходів, відбувся 30 квітня 2017 р., $з$ метою популяризації кімнати-музею вірменської культури в столичній бібліотеці ім. М. Реріха. Подібні свята супроводжуються декламацією українських i вірменських віршів та виконанням ліричних пісень [12]. Візьмемо для порівняння ці два музичні заходи (день народження О. Авагяна та літературно-музичний вечір у бібліотеці), та проаналізуємо їх призначення і відмінності. Існує 
певна різниця між моноетнічним та поліетнічним рівнем організації. Представники вірменської діаспори, згідно з статутом кожної з громад, прагнуть зберегти власну культуру, насамперед, за допомогою різноманітних заходів (таких як поетично-музичний вечір або тематична виставка). У той же час, заходи, влаштовані за допомогою кооперації 3 українськими представниками творчої інтелігенції, мають на меті не лише збереження, а й популяризацію вірменської культури в українському соціокультурному просторі. Яскравим прикладом такої співпраці стала Міжнародна науковопрактична конференція-фестиваль, проведена факультетом готельно-ресторанного та туристичного бізнесу Київського національного університету культури i мистецтв 25-26 жовтня 2017 р. Окрім доповідей, наданих кафедрою мов Національного університету архітектури і будівництва Вірменії, у фестивалі прийняли участь представники Київського приходського хору каплиці Србоц Наатакац, де пролунала народна класична вірменська пісня «Крунк»у виконанні А. Папікян та вірменський народний танок від Л. Григорян. Варто згадати ще один подібний захід, присвячений святкуванню Дня незалежності Вірменії, що відбувся 21 вересня 2016 р., на території національного заповідника «Софія Київська», в приміщенні храму Святої Софії. У цей день була проведена презентація шостого видання книги Н. Нікітенко «Від Царгорода до Києва» (у перекладі на вірменську мову). Сюжет книги заснований на розповіді про вірменку Анну Порфірородну, дружину київського князя Володимира. Свято супроводжувалось вірменськими церковними піснеспівами у виконанні згаданого 
Київського церковного хору. 3 огляду на масштабність заходу, можна стверджувати, що за сприяння вітчизняних культурних закладів та організацій, вірменські заходи трансформуються у всеукраїнський проект, результатом якого $\epsilon$, по-перше, популяризація вірменської цивілізації, по-друге, інтеграція вірмен в соціокультурний простір України, i, по-третє, культурне збагачення взаємодіючих етнічних спільнот.

Окрім Дня незалежності, вірмени усього світу відзначають інші світські свята, такі як: День материнства і краси, день захисту дітей, день виноградного врожаю тощо. Так, у 2017 р. до дня захисту дітей, що відзначається 1-го червня, вірменська громада Києва прийняла участь у Всеукраїнській ході на захист сім’ї і сімейних цінностей. За давньою традицією відбуваються щорічні святкування Пасхи, Різдва та ін. подій церковного календаря. Окрім повторюваних урочистостей, $\epsilon$ ще й одноразові: воздвиження купола, освячення хачкару, хреста, вівтаря. Наприклад, нещодавно відбулося урочисте відкриття вірменського храму в Луганську, де глава Української єпархії Вірменської Апостольської Церкви, єпископ Маркос Оганесян освятив надкупольний хрест і дзвін церкви Пресвятої Богородиці. Варто відзначити, що щорічно, розпочинаючи з 2014 р. (рік переосвячення Кам'янець-Подільської дзвіниці в церкву) вірменською громадою здійснюється паломництво до міста, яке супроводжується концертною програмою та екскурсійною частиною.

Урочистості на вшанування пам'яті жертв геноциду вірменського народу в Османській імперії відбуваються кожного 
року 24 квітня. Під час численних заходів у 2015 р. до століття геноциду в великих містах України (Одеса, Харків, Чернівці тощо) було встановлено і освячено більш ніж 20 хачкарів (прямокутна кам'яна стела з зображенням хреста й національних орнаментів).

Розмаїття національних костюмів, багатство візерунків та орнаментів, смак запашних страв, вироби майстер-класів 3 народних промислів, самобутні мелодії та ін. елементи, задіяні в національних урочистостях та святах не лише сприяють соціокультурній інтеграції етносів в українське суспільство, а й сприяють інтелектуальному й моральному просвітленню, усвідомленню людиною того, що вона може комфортно співіснувати 3 усіма етносами. В умовах глобалізації, усі етнічні заходи виховують відчуття толерантності, патріотизму і поваги до інших націй. Продемонструвавши, як натхненно представники національних меншин репрезентують свою культуру, природно зростає повага до загальнодержавної української культури. Отже, влаштовуючи різноманітні заходи культурного спрямування, вірмени не лише зберігають свою національну ідентичність в умовах діаспорального існування, а й збагачують культурну скарбницю всієї України, виконують інтерактивну, просвітницьку, розважальну та ін. функції в контексті розвитку українського суспільства.

У сучасному незбалансованому й конкурентному світі політична та економічна орієнтації окремих держав не завжди співпадає. Наявність широкої мережі активно діючих вірменських товариств у нашій країні $є$ важливим стабілізуючим фактором 
гармонізації міждержавних відносин України та Вірменії. Сдиною об’єднуючою організацією вірменських товариств України є Спілка вірмен України (СВУ). Організація щорічно проводить квартальні та підсумкові конференції, на яких ऑii центральні й регіональні представники звітують про введені проекти, заходи і плани. На підсумковій конференції, що відбулася 24 листопада 2017 р. у столичному готелі Hilton прозвучали численні доповіді про насичений подіями 2017 рік. На нашу думку, стрижневою тезою конференції стало вітальне слово міністра Республіки Вірменія в Україні, пана Г. Акопяна, який на прикладі успішного проведення виставки «Вірменські хачкари» в «Софії Київській», наголосив на пріоритетності робочої кооперації і єднання українського та вірменського народів. Також, в межах конференції відбувся показ соціального ролика «Я - як зерно гранату», авторами якого $€$ А. Берберян та А. Лідаговський, випускники КНУКіМу. Ролик присвячений 102-й річниці геноциду вірмен і має яскраве естетичне й символічне забарвлення. Вірменський народ представлений як зерна гранату (національний символ Вірменії), що розсіяні по всьому світу і прагнуть жити та процвітати. Цікаво, що режисер ролику А. Берберян, який виріс і навчався в Україні, має матір українку, а тата - вірменина. Враховуючи ці факти, складається враження, ніби юнак описує й свою долю за допомогою згаданого витвору кіномистецтва. Робота зайняла третє місце на фестивалі соціальної реклами «Molodiya Festival» та буде продемонстрована в рамках програми міжнародного фестивалю анімації KLIK в Амстердамі [16]. Концентра частина конференції об'єднала таких 
вітчизняних та зарубіжних зірок сучасного музичного мистецтва на одній сцені: Джамала, «The Hardkiss», С. Ханагян, А. Костандян, Араме.

Наукова новизна одержаних результатів полягає в тому, що вперше виявлено та проаналізовано різноманітні культурнодозвіллєві заходи вірменської діаспори в умовах незалежності України.

Висновки. У результаті дослідження виявлено, систематизовано та проаналізовано один із напрямків діяльності вірменських громад України, а саме: ï культурно-дозвіллєвий аспект. Охарактеризовано специфіку заходів вірменської громади, що проводяться 3 метою популяризації вірменської культури та всебічного розвитку загальноукраїнського культурного простору. 3 метою глибшого розуміння особливостей та місця вірменської культури в культуротворчому просторі України, запропонована їхня класифікація.

Перспектива подальших досліджень полягає у висвітленні іншого важливого напрямку діяльності вірменських громад, а саме: науково-просвітницький сектор.

\section{Список використаних джерел}

1. Бережна Н. Правове становище вірмен України у 1990-х 2000-х pр.(на матеріалах Черкаської громади) / Н. Бережна // Вісн. Черк. ун-ту. Історичні науки / Н. Бережна. - Черкаси, 2012. C. 111-116. 
2. В Киеве открылась выставка картин современных армянских художников [Электронный ресурс] // AnalitikaUa.2017. - Режим доступа : http://analitikaua.net/2017/v-kieve-otkryilasvyistavka-kartin-sovremennyih-armyanskih-hudozhnikov/. - Загл. с экрана.

3. В Киеве отметили 70-летие композитора Александра Авагяна [Электронный ресурс] // AnalitikaUa.- 2014.- Режим доступа : http://aspekty.net/2014/v-kieve-otmetili-70-letie-kompozitoraaleksandra-avagyana/. - Загл. с экрана.

4. В Киеве прошел творческий вечер Сергея Параджанова [Электронный ресурс] // AnalitikaUa. - 2009. - Режим доступа : http://analitika.at.ua/news/v_kieve_

proshel_tvorcheskij_vecher_sergeja_paradzhanova/2009-10-05-15007. Загл. с экрана.

5. В Украинском фонде культуры открылась выставка Марины Саркисян [Электронный ресурс] // AnalitikaUa. - 2017.Режим доступа: http://analitikaua.net/2017/v-ukrainskom-fondekulturyi-otkryilas-vyistavka-marinyi-sarkisyan/. - Загл. с экрана.

6. В Україні проходять Дні вірменської культури [Електронний ресурс] // Чернігівська обласна Державна телерадіокомпанія. - 2015. - Режим доступу : http://chodtrk.com.ua/?p=21442. - Назва з екрану.

7. Гаюк I. Специфіка дослідження культури вірменської діаспори в Україні / I. Гаюк // Мистецтвознавчі зап. / I. Гаюк. Київ : Міленіум, 2016. - С. 154-161. 
8. Дні культури Вірменії в Україні [Електронний ресурс] // Хрещатик. - $2005 . \quad-\quad$ Режим доступу: http://www.kreschatic.kiev.ua/ua/2698/art/26481.html. - Назва 3 екрану.

9. Дні культури Вірменії в Україні [Електронний ресурс] // Київська вірменська громада. - 2011.- Режим доступу : http://kievao.com.ua/index.php?option=com_content $\& v i e w=a r t i c l e \& i d=$ 355:2011-06-24-17-09-10\&catid=1:2009-08-19-22-3148\&Itemid=28>. - Назва з екрану.

10.Дятлов В. Армянская диаспора: очерки социокультурной типологии / В. Дятлов, Э. Мелконян. - Ереван : Институт Кавказа, 2009. - $207 \mathrm{c}$.

11.Конституція України / Верховна Рада України : офіц. вид. Київ : Парлам. вид-во, 2017. - 68 с.

12.Литературно-музыкальный вечер «Душа поет на армянском» [Электронный pecypc] // Hayern aysor. - 2017. - Режим доступа : http://hayernaysor.am/ru/archives/244782. - Загл. с экрана.

13.Оганесян. О. Всеукраїнському проекту «Моя Батьківщина - очима дітей етносів України»-10 років / О. Оганесян. - Київ : Вид. дім Дмитра Бураго, 2016. - 60 с.

14.Про кількість та склад населення України за підсумками Всеукраїнського перепису населення 2001 року [Електронний pecypc] // Держ. комітет статистики України. - 2003. - Режим доступу : http://2001.ukrcensus.gov.ua/results/general/nationality/. Назва з екрану. 
15.Псалом Вірменії. Великодні зустрічі [Електронний pecypc].- 2017. - Режим доступу : http://www.burago.com.ua/index.php/ua/novini/ literaturna-afishakieva/1398-psalom-armenii-paskhalnye-vstrechi-2. - Назва з екрану.

16.Ролик Союза армян Украины в тройке лучших на фестивале соцрекламы в Украине [Электронный ресурс] // AnalitikaUa. - 2017.- 2 Режим доступа : http://analitikaua.net/2017/rolik-soyuza-armyan-ukrainyi-v-troykeluchshih-na-festivale-sotsreklamyi-v-ukraine/. - Загл. с экрана.

17.Сборник стихов Василия Стуса на украинском и армянском языках презентовали в Киеве [Электронный ресурс] // Союз армянской молодежи Украины. - 2017.- Режим доступа : http://samu.net.ua/stus/. - Загл. с экрана.

18.Свято дружби народів outlook world festival пройшло iз повним аншлагом [Електронний ресурс] // Уніан. - 2017. - Режим доступу : https://www.unian.ua/common/2178716-svyato-drujbinarodiv-outlook-world-culture-festival-proyshov-iz-povnimanshlagom.html. - Назва з екрану.

19.Фестиваль Культури народів Подолу [Електронний ресурс] // ПРО. - 2017. - Режим доступу: http://www.ipro.kiev.ua/content/festival-kulturi-narodiv-podolu. - Назва з екрану.

\section{$\underline{\text { References }}$}

1. Analitika.at.ua, (2017). Author exhibition of Marina Sargsyan opened at the Ukrainian Culture Fund. Available at: 
http://analitikaua.net/2017/v-ukrainskom-fonde-kulturyi-otkryilasvyistavka-marinyi-sarkisyan/ [Accessed November 30, 2017].

2. Analitika.at.ua, (2017). The exhibition of paintings by contemporary Armenian artists opened in Kyiv. Available at: $<$ http://analitikaua.net/2017/v-kieve-otkryilas-vyistavka-kartinsovremennyih-armyanskih-hudozhnikov/> [Accessed November 30, 2017].

3. AnalitikaUa, (2017). The video of the Union of Armenians of Ukraine in the top three at the Socrates Advertising Festival in Ukraine. Available at: <http://analitikaua.net/2017/rolik-soyuza-armyan-ukrainyiv-troyke-luchshih-na-festivale-sotsreklamyi-v-ukraine/>

[Accessed November 4, 2017].

4. Analitika.at.ua, (2009). Sergey Parajanov's creative evening was held in Kyiv. Available at: <http://analitika.at.ua/news/v_kieve_proshel_tvorcheskij_ vecher_sergeja_paradzhanova/2009-10-05-15007> [Accessed November 30, 2017].

5. Aspekty.net. (2014). The 70th anniversary of composer Alexander Avagyan was celebrated in Kiev. Available: $<$ http://aspekty.net/2014/v-kieve-otmetili-70-letie-kompozitoraaleksandra-avagyana/> [Accessed November 10, 2017].

6. Berezhna, N. (2012). The legal status of the Armenians of Ukraine in the 1990s - 2000s (based on the materials of the Cherkassy community). Visnyk Cherkaskoho universytetu. Istorychni nauky [Bulletin of Cherkasy University. Historical sciences], no. 29, pp. 111116. 
7. Chernihiv Regional State Television and Radio Company, (2015). Days of Armenian Culture to take place in Ukraine. Available at: <http://chodtrk.com.ua/?p=21442>. [Accessed November 30, 2016].

8. The Constitution of Ukraine, (2017). Kyiv: Parlamentske vydavnytstvo.

9. Dmitry Burago Publishing House, (2017). Psalm of Armenia. Easter meetings Available at: $<$ http://www.burago.com.ua/index.php/ua/novini/literaturna-afishakieva/1398-psalom-armenii-paskhalnye-vstrechi-2>.

[Accessed November 12, 2017].

10. Dyatlov, V. and Melkonyan, E. (2009). The Armenian diaspora: the outlines of socio-cultural typology. Yerevan: The Caucasus Institute.

11. Haiuk, I. (2016). Specificity of the study of the culture of the Armenian diaspora in Ukraine Mystetstvoznavchi zapysky [Art critical notes], no. 29, pp. 154-161.

12. Hayren Aysor, (2017). Literary musical evening «Soul sings in Armenian» Available at: 〈http://hayernaysor.am/en/archives/244782〉. [Accessed November 1, 2017].

13. Information Agency of the Cultural Industry AB (2017). Festival of Cultures of the Peoples of Podil. Available at: <http://www.ipro.kiev.ua/content/festival-kulturi-narodiv-podolu.> [Accessed November 30, 2017].

14. Information agency UNIAN, (2017). The holiday of friendship of nations Outlook World Festival was held with full house. Available at: $<$ https://www.unian.ua/common/2178716-svyato-drujbi-narodiv- 
outlook-world-culture-festival-proyshov-iz-povnim-anshlagom.html> [Accessed November 5, 2017].

15. Kyiv Armenian community, (2011). Days of Armenian culture in Ukraine. Available at: <http://kievao.com.ua/index.php? option=com_content\&view=article\&id=355:2011-06-24-17-0910\&catid=1:2009-08-19-22- 31-48 \& Itemid $=28>$ [Accessed November 30, 2017].

16. Ohanesian, O. (2011). The 10th anniversary of the AllUkrainian project «My Homeland - Through the Eyes of the Children of Ethnic Ukraine». Kyiv: Dmitry Burago Publishing House, revised on November 18, 2017.

17. State Statistics Committee of Ukraine, (2003). On the number and composition of the population of Ukraine according to the results of the All-Ukrainian Population Census in 2001. Available at: <http://2001.ukrcensus.gov.ua/results/general/nationality/> [Accessed November 30, 2003].

18. The newspaper of Kyiv City Council Khreschatyk, (2005). Days of Armenian culture in Ukraine. Available at: <http://www.kreschatic.kiev.ua/ua/2698/art/26481.html.> [Accessed November 30, 2005].

19. The Union of Armenian Youth of Ukraine, (2017). Vasyl Stus's collection of poems in the Ukrainian and Armenian languages was presented in Kiev. Available at: <http://samu.net.ua/stus/> [Accessed November 20, 2017].

(C) Данник К. О., 2017 